\title{
Diffusion of Organic Agriculture in Russia: Features and Implications for Rural Development
}

\author{
R. G. Gracheva ${ }^{a, b}, *$ and A. V. Sheludkov ${ }^{a, b}, * *$ \\ ${ }^{a}$ Institute of Geography, Russian Academy of Sciences, Moscow, Russia \\ ${ }^{b}$ HSE University, Moscow, Russia \\ *e-mail: gracheva@igras.ru \\ **e-mail: a.v.sheludkov@igras.ru
}

Received June 23, 2021; revised July 13, 2021; accepted July 16, 2021

\begin{abstract}
In recent decades, organic agriculture has played an increasingly prominent role in the global and Russian agricultural sector. This trend emerged in opposition to industrial agrarian production, in response to growing demands for environmental protection and social justice. The article analyzes the place of organic agriculture among the agrarian systems of the mid-20th-early 21st centuries, the specifics of its development in Russia, and the geographical patterns of this process. In contrast to European countries, large investors initially gave impetus to development of the sector in Russia; the main motives of pioneers were associated with healthy eating and to a lesser extent with environmental or social issues. From the standpoint of the theory of diffusion of innovation, the development of organic agriculture is in its early stages; however, the number of farms and land areas under organic production are steadily growing, service industries and sales channels are being formed, and an institutional environment has been arisen in the form of industry associations and national legislation. The location of farms with different specializations can be traced to the dependence on natural conditions and the agrarian history of the territory. Refineries gravitate towards Moscow as the largest sales market. The last part of the article discusses the implications of organic agriculture for the development of rural areas in Russia: mitigating socioeconomic contrasts between suburban and peripheral rural areas, preserving the traditional cultural landscape and supporting rural tourism, and promoting environmental ideology in the agricultural sector and in society.
\end{abstract}

Keywords: agricultural systems, greening of agricultural production, diffusion of innovations, geography of agriculture, organic production

DOI: $10.1134 /$ S2079970521040055

\section{INTRODUCTION}

Agriculture, as a multifunctional and multifactorial field of activity, is closely linked to a wide range of natural resources and ecosystem services and plays an important social role in providing employment, lifestyle, and food security. In the 20th century, agriculture underwent a radical transformation under the influence of technological progress and new industrial forms of organization of production ("green revolution"); today it remains one of the main objects of technological innovation. In recent decades, in many ways in opposition to industrialization, the ideology of organic agriculture has been spreading around the world. It plays an increasingly prominent role in Russia's agricultural sector.

Since 2018, the term "organic products" has been enshrined in Russian national legislation. In a strict sense, organic production is considered to comprise only the activities of companies that are subject to the legislation and have passed the appropriate certifica- tion. However, the ideas and practices of greening and biologizing agriculture are much more widespread.

In foreign public and scientific discourse, the topic of organic agriculture has been heard over the past 20 years with increasing tension and a noticeable shift in the priorities of discussion towards social issues. The range of issues discussed is wide: the ability of organic agriculture to provide a growing population with food, efficiency in solving environmental and social problems, resilience in the face of climate change, sustainability of the organic system in the long term and the possibility of its renewal. Regular reports, guidelines, and other materials of international and national agricultural organizations (FAO, FiBL, IFOAM, etc.) are published, devoted to theoretical and practical issues of organic agriculture. In Russian publications, the topic of organic agriculture has not yet taken noticeable positions; it is not as diverse or conceptually formalized; it mainly deals with organizational issues in the formation of an organic segment in the Russian agricultural sector and often has an 
informational rather than analytical or debatable nature; see, e.g., (Mitina and Bykova, 2016; Mitusova and Buivolova, 2017; van Mansvelt and Temirbekova, 2017). Important evidence for the acknowledgment of organic agriculture as an integral part of the Russian agrarian sphere is the line of new courses at universities and new textbooks; see, e.g., (Organicheskoe ..., 2019).

In the English language literature, the term "organic" refers to a wide range of items associated with the production of organic products (not necessarily agricultural). In Russia, the language of production and market for agricultural products includes the concepts of "organic production," "organic products," "organic food shelf." However, more and more often, the word "organics" is used as a semantic catchall for both organic production itself and the industry as a whole.

The aim of this study is to determine the features of organic agriculture in Russia and its possible socioecological effects for the development of rural areas. In the following sections, we show the specifics of organic agriculture and its place in the historical row of the most important agricultural systems, from industrial agriculture of the "green revolution" era to modern trends in the greening of agricultural production. Against this background, the development of organic agriculture in Russia is analyzed: the stages of diffusion from the standpoint of the theory of diffusion of innovations, the geographical patterns of this process, its specificity and priorities in comparison with world experience; discusses the potential implications of organic agriculture for rural development. The results obtained are based on an analysis of publications and websites of organic producers in Russia and their associations, the legal framework regulating organic production, as well as interviews with individual participants in the formation of organic agriculture in the country.

\section{EVOLUTION OF AGRICULTURAL SYSTEMS IN THE WORLD}

The evolution of agricultural systems, which has been taking place over millennia in different regions of the world following natural and socioeconomic changes, has accelerated in the 20th century and became inclusive in the 21st century. Since the beginning of the 20th century, two main directions of this evolution have been clearly distinguished: industrialization, or intensification of agriculture, and the development of an alternative agricultural system, generally known as environmentally oriented or organic agriculture (Conford, 2001; Merill, 1983; Rigby and Cáceres, 2001; The World ..., 2021). These areas, which coexist and compete at the present time and have largely changed not only agriculture, but the world as a whole, differ sharply from each other in the main goals, methods, social content, and conse- quences of interaction with agricultural resources and the natural environment.

Industrialization, or intensification of agriculture, which began rapidly after the Second World War, spanned the 1940s-1970s. It was based on powerful and productive plant breeding and mechanization and chemicalization of agricultural production, aimed at providing food to the world's growing population, especially in developing countries, and these tasks were largely achieved (Agriculture ..., 1909; Conway, 2000; The State ..., 1981). The industrialization of agriculture meant an increase in the size of farms, combined with a high degree of specialization, dependence on nonagricultural and synthetic resources and processing industries (Lengnick et al., 2015). This period in the agrarian history of the world is called the Third Agrarian Revolution, following the Neolithic and British agrarian revolutions of the 17 th -19 th centuries (Pretty, 1991); in 1968, this stage was called the Green Revolution (Gaud, 1968). In the USSR, the course for the intensification of agriculture, developed even before the Second World War, was ultimately formalized in the early 1960s. The intensification of the industry, aimed, like in the world, at mechanization, chemicalization and specialization of agricultural enterprises along with agro-industrial integration, actively developed in the 1960s-1970s, but gradually lost its dynamism and efficiency (Ioffe et al., 1989; Smith, 1984).

If we take into account the modern meaning of the term "green" the Green Revolution as a symbol of agricultural intensification was, in fact, antigreen. The consequences were proliferation of monocultures, vast areas of degraded soils, declining water quality, declining biodiversity, unprecedented declines in food safety, and ruination of smallholder farmers (Agriculture ..., 2009; Altieri and Nicholls, 2012; Toward ..., 2010). From a modern point of view, agricultural intensification is exacerbating climate change: according to incomplete data, agriculture accounts for about $17 \%$ of greenhouse gas emissions (Emission ..., 2018). Extreme climatic events threaten genetically homogeneous monocultures, which currently cover about $80 \%$ of the world's arable land (Altieri et al., 2012). The requirements on product unification by large agricultural markets increase climate risks for growers who cannot choose varieties that are better adapted to local climatic conditions (Lengnick et al., 2015).

In response to the environmental demands and challenges posed by industrial agriculture, transnational agrarian movements have emerged, united by such goals as environmental friendliness, human health, and the prosperity of farming communities. In practice, these goals are achieved primarily in the system of organic agriculture, which requires the use of only agronomic and biological methods, a complete ban of synthetic substances, encouraging renewable energy sources and waste recycling, and focuses on 
small and medium-sized farmers (Conford, 2001; Pretty, 2008; Toward ..., 2010).

Since the 1980s, organic agriculture has experienced avalanche-like development, acquiring by the beginning of the 21st century institutional forms and legal status in most countries, receiving government support, clear certification rules, national organic standards (in the countries of the European Union there is a single organic standard), and having become an essential part of the green economy (Organic ..., 1999; Organic ..., 2002; Rigby and Cáceres, 2001; Taus et al., 2013). Whereas in 1985 in Europe, a pioneering 100000 ha were certified as organic, in 2020 organic farming occupied $16.5 \mathrm{mln}$ ha in Europe, and the growth continues. However, the largest "organic field," or rather, "organic pasture" is in the countries of Oceania: $35.9 \mathrm{mln}$ ha (The World ..., 2021).

At the same time, a powerful global industry appeared, producing biological products, equipment, and care products for organic farms, where Europe holds the lead. ${ }^{1}$

Organic agriculture has become part of the state environmental and food policy of the United States, the European Union, and many other countries (Moschitz and Stolze, 2010; Rotz et al., 2018; Egas and De Salvo, 2018; NOP ..., 2020). However, the main thing that supports the organic system is the interest and trust of society and involvement of people in agriculture, for whom environmental protection and "organics as a way of life" are more important than profit (Milestad and Darnhofer, 2003; Peterson et al., 2012).

In recent years, in addition to a large-scale movement against the dominance of industrial agriculture (Hendrickson and James, 2005), questions have arisen about the system of organic agriculture. The press of national organic standards, the growing consolidation of large organic corporations regulating the market, the dependence of farmers on the biopharmaceuticals market, and increased atmospheric $\mathrm{CO}_{2}$ emissions, which in aggregate limits the possibilities for diversifying agricultural crops, hinders the development and diversity of farms (Altieri et al., 2012; Clark, 2020; Foran et al., 2014; Land ..., 2018; Schieffer and Dillon, 2015; Sustainable ..., 2016). Agrarian movements have intensified, generally growing out of the organic paradigm, but rejecting its modern practical implementation, primarily, the dominance of monocultures and transformation into large-scale agriculture. This is an agroecological movement, which is gaining more and more supporters and is being implemented on many farms around the world, supporting small farmers and calling for a halt to spending on external resources, using the natural productivity potential of the agricul-

\footnotetext{
${ }^{1}$ Agricultural biologicals market analysis and segment forecasts to 2028, 2021. https://www.verifiedmarketresearch.com/product/agricultural-biologicals-market/. Accessed July 11, 2021.
}

tural landscape (Altieri et al, 2012; Gallardo-López et al., 2018; Kremen et al., 2012; Sustainable ..., 2016; Wezel et al., 2009).

Close to agroecological, the fast-growing regenerative agrarian movement focuses on the fight against climate change and also calls for the revival of local economies, independence of farmers, and achievement of social justice; see, e.g., (Dahlberg, 1994; Pearson, 2007; Schreefel et al., 2020). The movement was organized officially in 2015 as Regeneration International (RI), and its significance is evidenced by the fact that IFOAM-Organics International, an international umbrella organization in the field of organic production, acted as one of the founders of RI. ${ }^{2}$

In general, systems that have different weights in the modern global agrarian sphere-organic, agroecological, and regenerative agriculture-are currently competing for the best practices, and while their advocates are not cooperating, but competing with each other, they are acting in the interests of healthier nature and healthier and more equitable society.

The need for healthy food is especially noticeable during periods of external shocks: in the COVID-19 pandemic, retail sales of organic products in some countries grew by $30 \%$ (The World ..., 2021).

As will be shown below, in Russia's agricultural sector, the ideology of environmentally oriented activities is gradually spreading, which is implemented mainly in institutional forms of organic agriculture.

\section{DISTRIBUTION OF ORGANIC AGRICULTURE AS AN EXAMPLE OF DIFFUSION OF INNOVATIONS AND ITS GEOGRAPHICAL PATTERNS}

Rogers' classic innovation diffusion model (1983) describes the relationship between the rate of diffusion of innovations and the time since their inception using the S-curve: slow growth in the number of adopters, then accelerated growth, and, finally, the slowing down and reaching of a plateau with the maximum possible share of actors who have adopted the innovation (Fig. 1). Accordingly, from the beginning of the spreading of an idea/technology to its completion, specific groups of actors are distinguished - innovators, who are responsible for starting the process; early adopters, who take over the initiative from innovators until an early and then late majority is reached; and laggards, who for one reason or another do not accept the innovation for a long time, but in the end they too are forced to follow the example of the majority.

In European countries among innovators in organic agriculture, urban dwellers who had not previously been involved in agricultural production were often noted; they were younger and more educated than

\footnotetext{
${ }^{2}$ About Regeneration International. https://regenerationinternational.org/about-us/.
} 


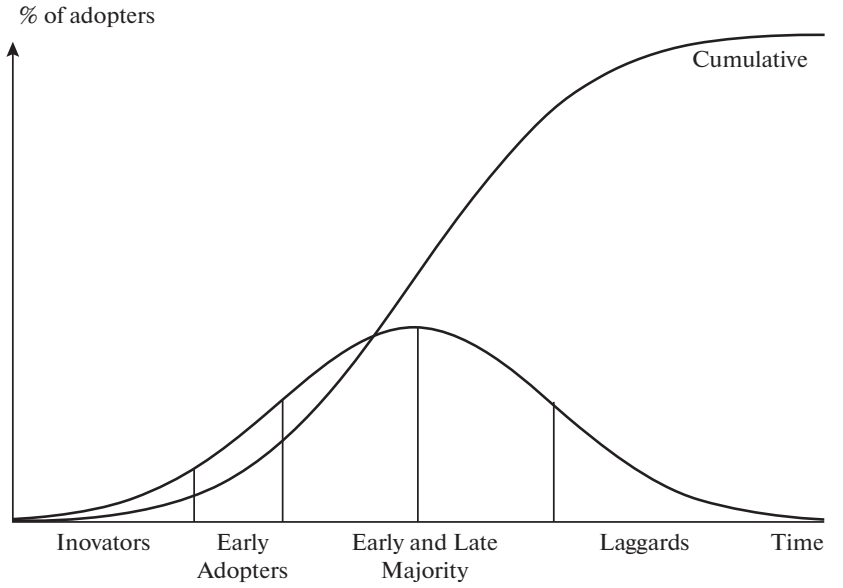

Fig. 1. Diffusion stages of innovation. Source: (Padel, 2001).

other farmers and came to agriculture influenced by ideas on the need for greening agricultural production; see, e.g., (Padel, 2001). Lacking experience and large assets, they create small farms, smaller than the average in size in their sector. Early adopters, as a rule, are more experienced farmers who decide on the transition from common industrial agriculture to organic, guided by economic motives. The number of early adopters has been growing following the development of institutional conditions: legal regulation of the organic market, government support measures, and marketing systems. They are better integrated into local communities, which accelerates the spread of organic production; with their appearance, the average size of farms has also increased.

In many countries, it is noted that organic agriculture is spatially unevenly distributed, so that producers often form stable clusters; see, e.g., (Allaire et al., 2015; Bjørkhaug and Blekesaune, 2013; Nyblom et al., 2003; Taus et al., 2013). There are two categories of factors that determine the spatial unevenness in the distribution of organic agriculture (Schmidtner et al., 2012). The first category includes traditional factors in the location of agricultural production, such as landscape and climatic conditions and distance to major sales markets. For example, in Germany and the USA, organic production developed mainly in regions with a low agroclimatic potential: less fertile soils and more severe winters, i.e., where industrial agriculture has fewer advantages (Kuo and Peters, 2017; Schmidtner et al., 2012). In Norway, organic production has been more successful in regions with a higher population density and, accordingly, greater opportunities for local marketing (Bjørkhaug and Blekesaune, 2013). In Korea, farmers near cities proved more susceptible to changes in the institutional environment in favor of organic production and more often have made the decision to convert their farms from industrial to organic (Choi, 2016). Landscape and climatic condi- tions also determine the specialization of farms, creating the basis for their clustering (Allaire et al., 2015).

The second group of factors is spatial interdependence, or neighborhood effect, which can have both positive and negative externalities. One negative externality is, e.g., the use of chemicals in fields, which limits the ability of neighboring farms to switch to organic production (Parker and Munroe, 2007). Positive externalities are primarily the opportunity to share experience and skills between local organic producers (directly or by demonstrating successful strategies (Boncinelli et al., 2015), social support (Läpple and Kelley, 2015), the emergence of maintenance services, specialized processing plants, and local distribution networks (Kuo and Peters, 2017). As a result, organic farming is increasing significantly in areas where it already exists (Allaire et al., 2015).

\section{DEVELOPMENT OF ORGANIC AGRICULTURE IN RUSSIA}

At the beginning of 2021, there were about 120-130 certified organic producers in Russia, according to the National Organic Union. ${ }^{3}$ Compared to European countries, such as France (47000 manufacturers ${ }^{4}$ ), Spain (41000), Germany (34000) or Poland (19000), this modest figure shows that the development of organic agriculture in Russia is in its very early stages. From 2010 to 2019, the area of certified organic agricultural land in Russia has grown 15 times: from 44000 to 674000 ha (according to FiBL, 2021) (Fig. 2). However, with respect to the total area of agricultural land in the country, the share of organic land did not exceed $0.35 \%$. For comparison, in the European Union, the share of certified farmland in 2019 was $8.1 \%$; in the world, $1.5 \% .^{5}$

\section{Innovators and Early Adopters}

The first Russian organic products appeared on store shelves in 2009 (O.V. Mironenko, interview). The next major milestones were the emergence of the first national standard in 2015 and entry into force of the law on organic products in 2020. In fact, all companies that started operating before 2020 , i.e., in an unformed institutional field, can to some degree be attributed to the category of innovators.

The first impetus to development of organic agriculture came from a large, usually noncore business, starting with the import of organic products. Thus, the importer, and later the manufacturer of organic prod-

\footnotetext{
${ }^{3}$ There are 60 manufacturers in the official state registry as of March 2, 2021: only manufacturers that have passed Russian certification are included in the register.

${ }^{4}$ Hereinafter, the figures are for 2019, according to FiBL data.

${ }^{5}$ FiBL. Data on Organic Agriculture in the World in 2000-2019, Frick: Research Institute of Organic Agric., 2021. https://statistics.fibl.org/data.html. Accessed May 23, 2021.
} 


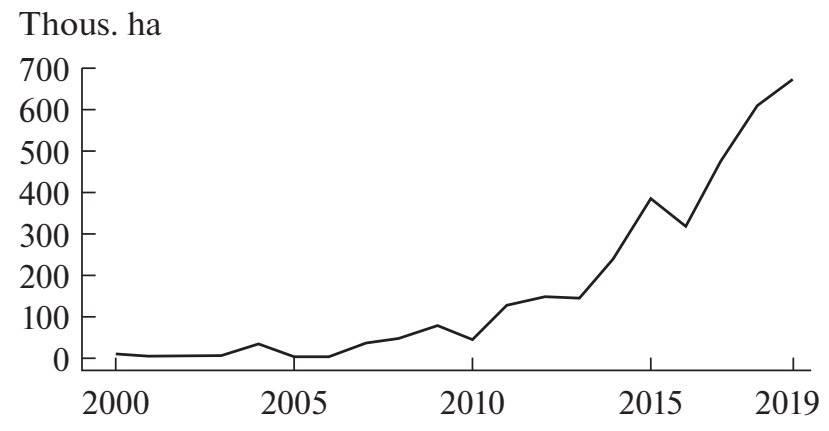

Fig. 2. Organic area in Russia.

Note: compiled from FiBL data (2021).

ucts, the Arivera company (Republic of Mordovia, Tula Oblast) was established in 2006 by the owners of commercial real estate in Moscow; Yaroslavl holding AgriVolga was founded in 2007 as part of the Agranta development group; Farm M2 (Volokolamsky district of Moscow Oblast) is a part of the Major Auto automobile holding. The organic production model was transferred from Western countries, where investors had experience of doing business or simply often visited; however, unlike European producers, the declared main motivation was not to transform agriculture to protect the environment, but to create their own healthy food products. Quite quickly, these companies grew into a big business, production became diversified, going even beyond the sphere of organic production itself (e.g., the main capacities of AgriVolga are currently aimed at the production of natural, i.e., without impurities, but not organic food), and, most importantly, the activities of the first companies helped spread the ideology of organic agriculture, forming both consumer and market.

The second category of innovators is experienced farmers who have converted part of their production or completely switched to organic farming. It is important that the main motivation here was not commercial prospects, but adherence to the principles of healthy eating. An example of such a company is Nauka Plus in Krasnodar Krai. The company's main specialization is soybeans and rice. In 2011, the owners of the company began to cooperate with Italians, received training in organic farming, purchased equipment, and later converted some of the fields to organic production. Since 2012, the company has been working with international certification organizations; in 2017, organic rice was grown in certified fields and received international certification. In 2016, their own plant for production of various rice cereals was established (S.M. Berezovskaya, interview).

Organization of processing is one of the difficulties that small organic farms face: processing plants oriented towards an industrial producer are not interested in small orders. In addition, the processing itself must also be certified-special requirements are imposed right down to packaging. Therefore, organic producers like Nauka Plus often create their own processing lines.

Finally, the third category of innovators is townspeople without large capital or experience in agriculture, but who were able to create successful farms. Such farms include, e.g., a grain and flour producer from Tula Oblast, Chernyi Khleb. ${ }^{6}$

The fact that the Russian organic market is gradually moving to a more mature stage of development is signaled by the emergence of early adopters. These include large companies that have been on the market for a long time and have partially converted production towards organic farming. So far, we are talking mainly about processors: these are Nestlé and HIPP (baby food), Paulig (coffee), REMIT (meat products). Large agricultural producers include EkoNiva holding; in 2012-2015, one of its enterprises, the Savinskaya Niva livestock farm (Kaluga Oblast), completely switched to production of organic products. In addition, a whole group of organic vodka producers formed in Russia-in Udmurtia and Mordovia; Moscow, Tver, and Ulyanovsk oblasts; and Perm and Altai krais. Producers of organic fertilizers have appeared (at the beginning of 2021 there were nine), as well as distribution channels. Initially, producers of organic products were forced to create their own points of sale; e.g., since 2012, AgriVolga has had a chain of stores called Ugleche Pole Organic Market. However, today, online stores and supermarket chains are becoming important allies of organic producers, e.g., Azbuka Vkusa, Hyperglobus, Perekrestok, where separate shelves of organic products are created, and products of Russian manufacturers can be sold, including under the retail brands. ${ }^{7}$ However, for small farmers, marketing remains a problem, especially in regions far from Moscow, where demand is still amorphous. Sales here are still oriented towards the local market and are largely random (according to local media).

Along with certified organic producers, there are noncertified farms that use elements of organic or agroecological approaches in their activities. Since 2010, the center of permaculture (permanent agriculture) by Z. Holzer has been operating in Russia. Permaculture involves the creation of a consciously designed self-sustaining agricultural landscape that imitates natural patterns and relationships (Ferguson and Lovell, 2014). Several enterprises operate within this paradigm, e.g., Permapark Sochi, the Nova Russa farm in the Novgorod Oblast, Aktivnaya Konyushnya (Active Stable) and the Yasno Pole ecopark in Tula oblast, etc. ${ }^{8}$ In addition, individual farms have been

\footnotetext{
${ }^{6}$ Official site of the company. http://www.hlebio.ru.

${ }^{7}$ E.g., VITO Organic in Hyperglobus; Green Line Organic in Perekrestok; etc.

${ }^{8}$ Holzer Russian Center for Permaculture. Naturbook. https://naturbook.center/.
} 
Table 1. Legal acts on production of organic products in Russia

\begin{tabular}{|c|c|c|}
\hline $\begin{array}{c}\text { Adopted (entered } \\
\text { into force) }\end{array}$ & Status & Legal act \\
\hline $2014(2015)$ & Federal, acting & GOST R 56104-2014 Organic food products. Terms and definitions \\
\hline $2016(2017)$ & Federal, acting & $\begin{array}{l}\text { GOST R 57022-2016 Organic Products. Procedure for voluntary certification of } \\
\text { organic production }\end{array}$ \\
\hline $2016(2018)$ & Interstate, acting & $\begin{array}{l}\text { Interstate standard GOST 33980-2016 Organic products, rules for production, pro- } \\
\text { cessing, labeling, and sale (CAC/GL 32-1999, NEQ) }\end{array}$ \\
\hline $2018(2020)$ & Federal, acting & $\begin{array}{l}\text { Federal Law no. 280-FZ On Organic Products and Amendments to Certain Legisla- } \\
\text { tive Acts of the Russian Federation }\end{array}$ \\
\hline $2021(2021)$ & Federal, acting & $\begin{array}{l}\text { GOST R 59425-2021 Organic products from wild-growing raw materials. Rules for } \\
\text { collection, procurement, processing, storage, transport, and labeling }\end{array}$ \\
\hline
\end{tabular}

refraining from synthetic fertilizers and pesticides, fitting land into the natural landscape, creating forage grass ecosystems that improve soils and multitiered mixed crops (steppe-like), crop rotation, and sparing soil cultivation methods (Gulyanov, 2020). It is extremely difficult to judge their quantity and market share, because, unlike the organic label, the labels "eco" and "bio" can be freely used by any manufacturer.

Thus, in contrast to other countries, in Russia, large business initially played an important role in creating organic production; priority was given to issues of healthy eating, while environmental and social effects came second. From the standpoint of the theory of diffusion of innovations, the organic market in Russia is showing signs of incipient transition to a more mature stage, which is characterized by the emergence of a larger number of early adopters and the formation of such structural elements as service industries and distribution channels. An important condition for this was the formation of an institutional environment, primarily national legislation.

\section{Institutionalization of the Organic Market}

In 2013-2014, the two largest associations of organic producers appeared: the National Organic Union $^{9}$ and the Union of Organic Farming. ${ }^{10}$ The National Organic Union includes certified organic producers and retail representatives interested in developing the "shelf" of organic products. The members of the Union of Organic Agriculture are both producers of organic products and farms that advocate the biologization of agriculture. Industry associations have played and continue to play an important role in the maintenance and development of organic agriculture: they participated in the development of federal law and national standards, hold thematic conferences and training seminars, collect and analyze data, and

\footnotetext{
${ }^{9}$ National Organic Union. https://rosorganic.ru.

${ }^{10}$ Union of Organic Farming. https://soz.bio.
}

contribute to spreading the ideology of organic agriculture.

Prior to the entry into force of the law on organic production in 2020 (see below), Russian companies received European and American certificates, although, as a rule, they did not plan on supplying products to European markets. In addition to the economic difficulties of entering European markets, there were also institutional barriers. For example, when crossing the border, food products had to undergo quarantine processing, which deprived them of their organic status. ${ }^{11}$ In the domestic market, the main problem was so-called greenwashing: in the absence of legislative regulation, the food market was filled with industrial products, which were positioned as organic, which actually entailed the deception of consumers and undermined the activity of bona fide producers.

In 2017, at a meeting between the Yaroslavl business sphere and the President of the Russian Federation, representatives of organic agriculture came up with an initiative to create a national law on organic agriculture. Federal Law no. 280-FZ On Organic Products and Amendments to Certain Legislative Acts of the Russian Federation was adopted on August 3, 2018 , and entered into force on January 1, 2020. A specific feature of the law is the presence of benchmark norms: it does not give direct definitions, but refers to national standards developed and adopted earlier in 2014-2018 (Table 1). In addition, in 2021, new standards come, or will come, into force that regulate the assessment of soils in organic farming, the production of biological products for plant protection, and the use of graphic labeling of organic products.

Thus, with adoption of the law and national standards, formal grounds for combating greenwashing appeared in Russia, along with Russian certification companies (at the beginning of 2021 there were eight),

\footnotetext{
${ }^{11}$ This requirement disappeared with passage of the law in 2018.
} 


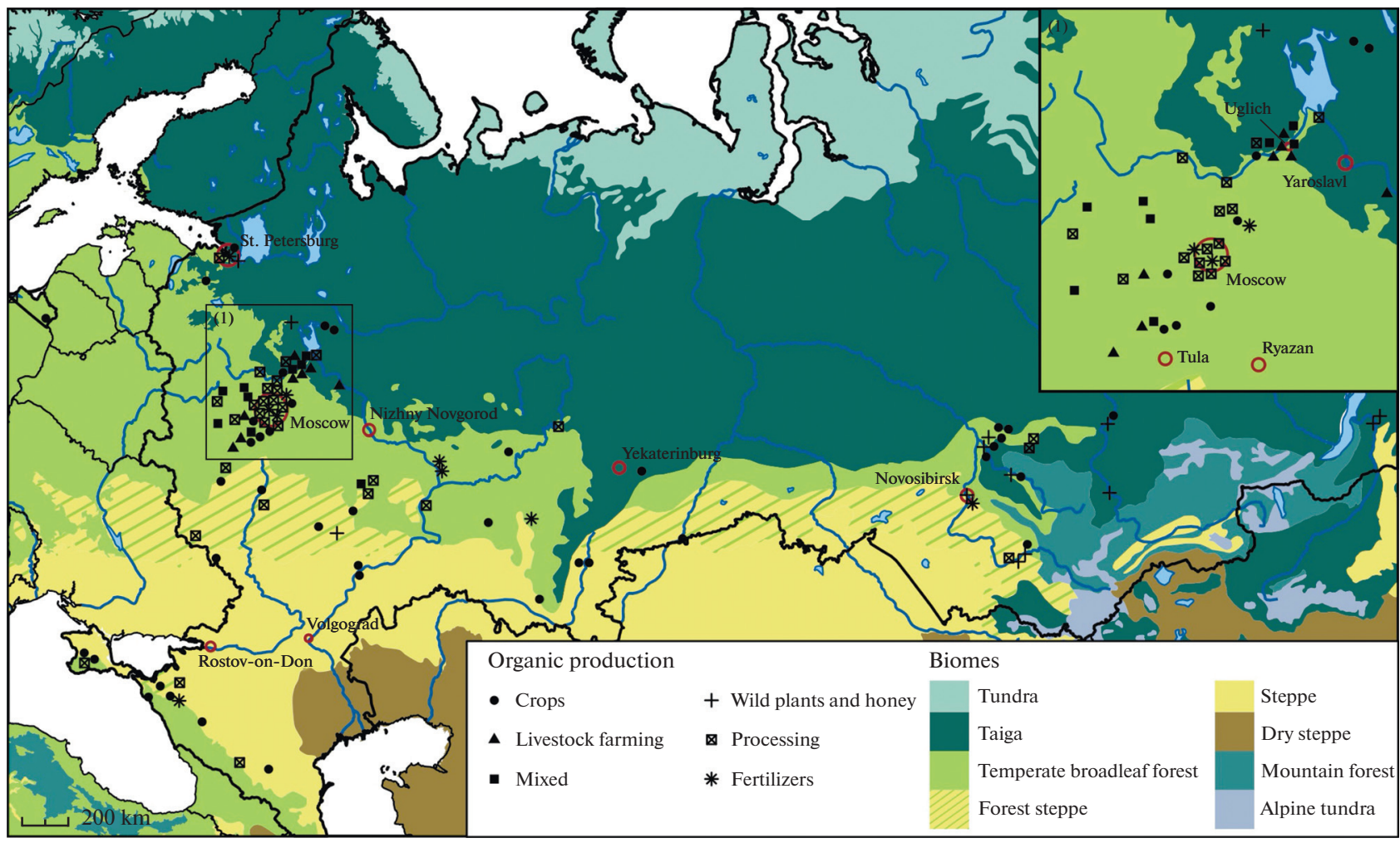

Fig. 3. Organic producers in Russia.

Compiled by authors based on data from National Organic Union; biome boundaries after (Olson et al., 2001).

labeling of organic products, and a state registry of organic producers. ${ }^{12}$

As a rule, the process of conversion from industrial to organic agriculture takes at least three years: the producer needs to prepare the land, build a production and distribution chain, and pass certification. Therefore, an important component of the institutional field in which organic agriculture develops are programs for its state support, including for the period of conversion. ${ }^{13}$ There is no such program at the federal level, but some regions, even before adoption of the federal law, were proactively building their own institutional field, including programs to support organic producers. The pioneer was Belgorod oblast, where in 2011 a program for the biologization of agriculture was adopted through the development of crop rotation, use of organic fertilizers and biological products, and development of beekeeping; in 2015, the Conscientious Land User Code was introduced. In 2013, laws on organic products appeared in Krasnodar krai and Ulyanovsk oblast, and in 2014, in Voronezh oblast. Among the regions where measures have been taken to

\footnotetext{
${ }^{12}$ Ministry of Agriculture of the Russian Federation. Unified State Registry of Organic Producers. http://opendata.mcx.ru/opendata/7708075454-organicprod.

${ }^{13}$ For example, in the EU, measures to support conversion have been in effect since 1992 (Mitusova and Buivolova, 2017).
}

support organic producers are Tomsk oblast and the republics of Tatarstan and Bashkortostan. The motivation of the regional authorities is based on two provisions: on the one hand, organic farming is a way to protect agricultural land under its increasing intensive use (Belgorod oblast was the first to take this path); on the other hand, the production of organic products provides the opportunity to support small farms in the face of competition from large holdings, stimulating their transition to a separate market niche; vivid examples are Voronezh oblast and the Republic of Tatarstan.

\section{Geographic Factors in the Location of Organic Farms}

Considering the small number of Russian producers of organic products, it is too early to talk about stable geographical patterns of their placement. Nevertheless, certain patterns associated with geographic factors are already noticeable today (Fig. 3).

First of all, there is clustering of processing enterprises near Moscow as the largest sales market. To the north, in the Non-Chernozem Zone, on lands where synthetic substances have not been introduced for about 20 years, livestock and fodder farms are developing. The cluster of enterprises of AgriVolga holding in Uglich district of Yaroslavl Oblast stands out. An additional factor in favor of the emergence of organic 
production in the region is that in the post-Soviet period these territories experienced a significant contraction in cultivated areas (Lyuri et al., 2010); therefore, chemical impact on fields and the environment as a whole has decreased. ${ }^{14}$

Mainly crop farms predominate in a wide strip from the border with Ukraine, Krasnodar Krai, and Ciscaucasia, the Volga Region, and Southern Siberia, on Chernozems of forest-steppes, steppes, and gray soils (Phaeozems) in the deciduous forest zone. A large cluster has formed in Tomsk oblast, where manufacturers are export-oriented. ${ }^{15}$ Lastly, farms in Siberia and the Far East that harvest wild plants form a separate group.

In many ways, the appearance of innovators in one place or another was of an accidental nature, being associated with the personal stories of investors and farmers. However, with the appearance of the first organic producers in the region, neighborhood externalities begin to work. In Kuban region, farmers had to struggle for a long time with neighbors who pollinated crops from planes, so that chemicals inevitably got into organic fields. However, over time, neighboring farmers themselves began to experiment in their fields, reducing the amount of chemicals used, practicing crop rotation, etc. (S.M. Berezovskaya, interview).

Agro-climatic conditions and agrarian experience of the population in many territories of Russia favor the development of organic agriculture; however, this potential has not yet been used. Such territories include the old-developed regions of the Non-Chernozem Zone, e.g., opolye area, ${ }^{16}$ with their Chernozem-like soils, and the basin of Lake Nero, on whose sapropel sediments the "vegetable garden" of Russia existed. Another example is the mountainous regions of the North Caucasus, where chemical fertilizers have never been used and agro-terraces have played a special role, regulating the water regime of slopes and slowing soil erosion. Since the second half of the 20th century, terraced slopes, which accounted for about $60 \%$ of all cultivated mountain lands in the North Caucasus, were abandoned (Gracheva et al., 2018). Terraces can be used by small farms for the production of high-quality organic products, which, combined with the tourist attraction of mountainous regions, will give a new impetus to their socioeconomic development.

\footnotetext{
14"When an investor bought land, they were abandoned .... These lands have not been cultivated with chemistry for $10-20$ years. That is, they were gorgeous lands for organic matter." From an interview with AgriVolga, Yaroslavl oblast.

${ }^{15}$ The largest exporter of organic products in Russia is Siberian Organic Products (Tomsk Oblast).

${ }^{16}$ The areas with better drainage conditions and soil quality in the Non-Chernozem Zone.
}

\section{IMPLICATIONS OF ORGANIC AGRICULTURE} FOR RURAL DEVELOPMENT

We believe that the specific features of organic agriculture, which are associated with production technology and underlying ideology, create potential positive externalities on the development of rural areas. Organic agriculture resists the trend towards concentration and specialization of agricultural production, helps to soften the socioeconomic contrasts between peri-urban and peripheral areas, creating new industries and jobs, and supports the traditional cultural landscape and rural tourism.

In industrial agriculture, large processing enterprises are usually located in cities and their surroundings, i.e., close to sales markets and large labor markets, and small raw material farms move to the periphery (Sheludkov, 2019). Particularly strong tendencies towards the concentration of industrial production are observed in animal husbandry, where huge complexes are created for several thousand head of livestock (Bogachev, 2017; Nefedova, 2017). Organic enterprises, being on average larger than foreign ones, are much smaller than Russian industrial farms and are less subjected to territorial concentration. The technology of organic livestock breeding does envisage the simultaneous maintenance of a large livestock, since certain standards of keeping and sanitary requirements are in force and free land is needed for grazing. Even if we are talking about a holding, its natural form of organization is dispersed: several enterprises in different places, and often from where industrial production has already moved out.

In addition, organic farming resists the trend towards strict specialization: many farms have a full production cycle from folder cultivation to finished product. As a result, jobs remain or appear in remote areas, ${ }^{17}$ and these are places requiring special qualifications. In response, many regional universities have specialized disciplines and educational courses devoted to organic agriculture: in Yaroslavl, Kazan, Krasnodar, Kaluga, and other cities.

One of the signs of the maturing of organic production is the emergence of Russian producers of organic fertilizers, biological products, and feed. In 2021, there are no more than ten, and this is a very low figure compared to the huge global industry aimed at meeting the most diverse needs of organic farming. ${ }^{18} \mathrm{How}-$ ever, this is the beginning of the process, and producers are actively involved in promoting organic agricul-

\footnotetext{
17 "First of all, when we got there, we gave people a place to work. Because the watch factory has gone down there already ... Besides tourism, in the summer when the cruise liner moors ... In general, it was problematic with employment there. We have actually given a thousand new jobs ...” (from an interview with AgriVolga).

${ }^{18}$ Agricultural biologicals market analysis and segment forecasts to 2028,2021 . https://www.verifiedmarketresearch.com/product/agricultural-biologicals-market/. Accessed July 11, 2021.
} 
ture, its environmental and social goals, such as creating conditions for the professional development of employees and revival of the Russian countryside. ${ }^{19}$

Organic agriculture contributes to the preservation of the traditional cultural landscape by preventing land degradation and creating agricultural landscapes that are consistent with the natural appearance of the territory and traditional land use patterns. At the same time, the new production buildings are not only functional, but also do not aesthetically disrupt the harmony of the locale, removing traces of abandonment and depressiveness in the territory. This is valuable in itself, but in addition, organic farming is often associated with the development of agro- or rural tourism; see, e.g., (Bjørkhaug and Blekesaune, 2013; Khanal et al. 2019; Privitera, 2010). This is true for both large and small farms. One of the basic principles of rural tourism is nutrition with products produced and grown in the area. Thus, the mentioned M2 farm (Shulgino) in Volokolamsky district of Moscow Oblast is part of a complex with guest houses. Smaller organic businesses also often run their own tourism business, supplying guests with their products. This link between organic agriculture and rural tourism is supported by associations of organic producers with tour operators, which was especially evident during the COVID-19 pandemic.

\section{CONCLUSIONS}

The development of organic agriculture in Russia is in its very early stages, spanning just over ten years. The spread of organic enterprises is subjected to the most direct and predictable patterns so far: prevalence in the European part of the country, concentration of processing enterprises in the cities, predominance of animal husbandry north of Moscow, in the areas of former dairy farming, crop orientation of farms in the Chernozem zone, including Southern Siberia, and predominance of companies harvesting and processing wild plants in the taiga regions east of the Urals.

The organic movement in Russia began and continues owing to big investors, not necessarily specialized ones, and individual enthusiasts, who often acquired experience and support abroad. Let us note the differences in the declared motivations when creating organic farms. In the pioneering countries of organic agriculture, producers were motivated to respond to social movements by nature conservation, product safety, i.e., human health, and social issues that have become increasingly important over time (Agriculture ..., 2009; Conford, 2001; Hendrickson and James, 2005; Merrill, 1983; Pretty, 2008; Toward ..., 2010). At the formation stage of organic farms in Russia, first place is given to the production of high-quality products; i.e., it is about human health. However, both producers involved in the

\footnotetext{
${ }^{19}$ Agroeco. Company group. https://agroeco.ru.
}

organic process and farmers outside the certified organic circle have a strong understanding of the interdependence of agriculture and conservation. Social issues are still rarely cited as the principles on which organic farming is based.

The legacy of the era of agricultural intensification is manifested in Russia in larger organic farms in comparison to Europe, but they are still much smaller than industrial agrarian enterprises and are less prone to territorial concentration.

Compared to the scale and speed of knowledge spread, establishment and certification of organic farms in many countries, these processes are much slower in Russia. The law has undoubtedly increased interest in organic production and its products by defining and enshrining standards, and informing the consumer about organic production and its products; organic products have become more popular and labels more recognizable.

However, despite the ongoing formation of the institutional environment, weak support from public institutions, such as professional communities, organized communities of consumers (buyers), science and media, and most importantly, the lack of effective support from the state, seriously slow the development of the organic sector of the agricultural economy, especially for small and medium-sized farms. A strong national system of quality assurance for organic products has not yet taken shape in Russia, hence the possibility of the emergence of unscrupulous producers and understandable distrust of buyers faced with more expensive organic products. We add here the lack of a well-established information work both with the agricultural sector and with consumers, the inaccessibility of manuals for managing organic farming, and the complexity of the certification process.

Nevertheless, over the past decade, an important institutional framework has been created, a community of organic producers has emerged, a completely new market for biological products for agriculture has formed, foreign experience is being actively mastered, and consumer interest in organic agricultural products is growing. All this makes it possible to forecast more dynamic development of organic agriculture in Russia.

\section{ACKNOWLEDGMENTS}

The authors are especially grateful to S.M. Berezovskaya, O.V. Mironenko, and S.B. Nosov for kindly providing information and participation in interviews.

\section{FUNDING}

The article was prepared in the framework of a research grant funded by the Ministry of Science and Higher Education of the Russian Federation (grant ID: 075-15-2020928). 


\section{CONFLICT OF INTEREST}

The authors declare no conflict of interest.

\section{REFERENCES}

Agriculture at a Crossroads: The Global Report, McIntyre, B.D., Herren, H.R., Wakhungu, J., and Watson, R.T., Eds., Nairobi: UNEP, 2009.

Allaire, G., Poméon, T., Maigné, E., Cahuzac, E., Simioni, M., and Desjeux, Y., Territorial analysis of the diffusion of organic farming in France: between heterogeneity and spatial dependence, Ecol. Indic., 2015, vol. 59, pp. 70-81.

Altieri, M.A., Nicholls, C.I., and Funes, F., Agroecology scaling up for food sovereignty and resiliency, in Sustainable Agriculture Reviews, Lichtfouse, E., Ed., Dordrecht: Springer-Verlag, 2012, vol. 11, pp. 1-29. https://doi.org/10.1007/978-94-007-5449-2_1

Bjørkhaug, H. and Blekesaune, A., Development of organic farming in Norway: a statistical analysis of neighborhood effects, Geoforum, 2013, vol. 45, pp. 201-210.

Bogachev, D.V., Transformation of the agriculture in Russia: significance of present-day vertical integration, Reg. Res. Russ., 2015, vol. 5, no. 4, pp. 392-401.

Boncinelli, F., Bartolini, F., Brunori, G., Casini, L., et al., Spatial analysis of the participation in agri-environment measures for organic farming, Renewable Agric. Food Syst., 2015, vol. 31, no. 4, pp. 375-386.

Choi, H., A typology of agro-innovation adoptions: the case of organic farming in Korea, Reg. Environ. Change, 2016, vol. 16, no. 6, pp. 1847-1857.

Clark, S., Organic farming and climate change: the need for innovation, Sustainability, 2020, vol. 12, p. 7012.

Conford, F., The Origins of the Organic Movement, Edinburgh: Floris Books, 2001.

Conway, G., Food for all in the 21st century, Environ.: Sci. Policy Sustainable Dev., 2000, vol. 42, no. 1, pp. 8-18. https://doi.org/10.1080/00139150009604857

Dahlberg, K.A., Regenerative food systems: broadening the scope and agenda of sustainability, in Food for the Future: Conditions and Contradictions of Sustainability, Allen, P., Ed., New York: Wiley, 1993, pp. 75-102.

Egas, J.J. and De Salvo, C.P., Agricultural Support Policies in Latin America and the Caribbean: 2018 Review, IDB Monograph No. 621, Washington, DC: Int.-Am. Bank Dev., 2018.

Emissions Due to Agriculture. Global, Regional and Country Trends 2000-2018, Rome: UN Food Agric. Org., 2018. http://www.fao.org/3/cb3808en/cb3808en.pdf. Accessed July 11, 2021.

Ferguson, R.S. and Lovell, S.T., Permaculture for agroecology: design, movement, practice, and worldview. A review, Agron. Sustainable Dev., 2014, vol. 34, no. 2, pp. $251-274$.

https://doi.org/10.1007/s13593-013-0181-6

Foran, T., Butler, J.R.A., Williams, L.J., Wanjura, W.J., Hall, A., and Carter, L., Taking complexity in food systems seriously: an interdisciplinary analysis, World Dev., 2014, vol. 61, pp. 85-101.

Gallardo-López, F., Hernández-Chontal, M.A., CisnerosSaguilán, P., and Linares-Gabriel, A., Development of the concept of agroecology in Europe: a review, Sustainability, 2018, vol. 10, no. 4, 1210.

https://doi.org/10.3390/su10041210

Gaud, W.S., The green revolution: accomplishments and apprehensions, 1968. http://www.agbioworld.org/biotech-info/topics/borlaug/borlaug-green.html. Accessed July 11, 2021.

Gracheva, R., Belonovskaya, E., and Vinogradova, V., Mountain grassland ecosystems on abandoned agricultural terraces (Russia, North Caucasus), Hacquetia, 2018, vol. 17 , no. 1 , pp. $61-71$.

https://doi.org/10.1515/hacq-2017-0010

Gulyanov, Yu.A., Steppes of Orenburg oblast: from breadbasket region to landscape health resort of Russia, Vopr. Stepeved., 2020, no. 1 (16), pp. 70-79.

Hendrickson, M.K. and James, H.S., The ethics of constrained choice: How the industrialization of agriculture impacts farming and farmer behavior, J. Agric. Environ. Ethics, 2005, vol. 18, pp. 269-291. https://doi.org/10.1007/s10806-005-0631-5

Ioffe, G.V., Nefedova, T.G., and Runova, T.G., Intensification of agriculture in the European USSR: regional aspects, Sov. Geogr., 1989, vol. 30, no. 1, pp. 49-64, https://doi.org/10.1080/00385417.1989.10640761

Khanal, A.R., Mishra, A.K., and Omobitan, O., Examining organic, agritourism, and agri-environmental diversification decisions of American farms: are these decisions interlinked? Rev. Agric., Food Environ. Stud., 2019, vol. 100, no. 1, pp. 27-45.

Kremen, C., Iles, A., and Bacon, C., Diversified farming systems: an agroecological, systems-based alternative to modern industrial agriculture, Ecol. Soc., 2012, vol. 17, no. 4 , p. 44.

https://doi.org/10.5751/ES-05103-170444

Kuo, H.J. and Peters, D.J., The socioeconomic geography of organic agriculture in the United States, Agroecol. Sustainable Food Syst., 2017, vol. 41, nos. 9-10, pp. 1162-1184.

Land Use and Food Security in 2050: a Narrow Road. Agrimonda-Terra, Le Mouël, C., de Lattre-Gasquet, M., and Mora, O., Eds., Paris: Quae, 2018.

Läpple, D. and Kelley, H., Spatial dependence in the adoption of organic drystock farming in Ireland, Eur. Rev. Agric. Econ., 2015, vol. 42, no. 2, pp. 315-337.

Lengnick, L., Miller, M., and Marten, G.G., Metropolitan foodsheds: a resilient response to the climate change challenge? J. Environ. Stud. Sci., 2015, no. 5, pp. 573-592. https://doi.org/10.1007/s13412-015-0349-2

Lyuri, D.I., Goryachkin, S.V., Karavaeva, N.A., Denisenko, E.A., and Nefedova, T.G., Dinamika sel'skokhozyaistvennykh zemel' Rossii v XX veke i postagrogennoe vosstanovlenie rastitel'nosti i pochv (Dynamics of Agricultural Lands of Russia in the 20th Century and Postagrogenic Recovery of Vegetation and Soils), Moscow: GEOS, 2010.

Merrill, M.C., Eco-agriculture: a review of its history and philosophy, Biol. Agric. Hortic., 1983, vol. 1, no. 3, pp. $181-210$.

https://doi.org/10.1080/01448765.1983.9754395 
Milestad, R. and Darnhofer, I., Building farm resilience: the prospects and challenges for organic farming, $J$. Sustainable Agric., 2003, vol. 22, no. 3, pp. 81-97.

Mitina, E.A. and Bykova, T.O., Ecologically clean products: standardization, certification, and state support of manufacturers, Prod. Polit. Bezop., 2016, vol. 3, no. 2, pp. 91-104.

Mitusova, Yu.A. and Buivolova, A.Yu., Development of organic agriculture in Russia, in Prodovol'stvennaya bezopasnost' $v$ Evraziiskom regione (Food Security in Eurasian Region), Moscow: Ekspert, 2017, pp. 7-30.

Moschitz, H. and Stolze, M., The influence of policy networks on policy output. A comparison of organic farming policy in the Czech Republic and Poland, Food Policy, 2010, vol. 35, no. 3, pp. 247-255. https://doi.org/10.1016/j.foodpol.2009.12.009

Nefedova, T.G., Twenty-five years of Russia's post-Soviet agriculture: geographical trends and contradictions, Reg. Res. Russ., 2017, vol. 7, no. 4, pp. 311-321.

NOP compliance and enforcement, USDA organic, 2021. https://www.ams.usda.gov/sites/default/files/media/CE_Overview_NOSBOct\%202020_Rakola.pdf. Accessed July 11, 2021.

Nyblom, J., Borgatti, S., Roslakka, J., and Salo, M.A., Statistical analysis of network data-an application to diffusion of innovation, Soc. Networks, 2003, vol. 25, no. 2 , pp. $175-195$.

Olson, D.M., Dinerstein, E., Wikramanayake, E.D., et al., Terrestrial ecoregions of the world: a new map of life on Earth, Bioscience, 2001, vol. 51, no. 11, pp. 933-938.

Organic agriculture, FAO, 1999. http://www.fao.org/organicag/oa-faq/oa-faq1. Accessed July 11, 2021.

Organic Agriculture, Environment and Food Security, ElHage Scialabba, N. and Hattam, C., Eds., Rome: UN Food Agric. Org., 2002.

Organicheskoe sel'skoe khozyaistvo v sisteme ustoichivogo razvitiya sel'skikh territorii: uchebnik (Organic Agriculture in the System of Sustainable Development of Agricultural Territories: Manual), Polushkina, T.M., Ed., Saransk: Modovsk. Gos. Univ., 2019.

Padel, S., Conversion to organic farming: a typical example of the diffusion of an innovation? Sociol. Ruralis, 2001, vol. 41 , no. 1 , pp. 40-61.

Parker, D.C. and Munroe, D.K., The geography of market failure: edge-effect externalities and the location and production patterns of organic farming, Ecol. Econ., 2007, vol. 60, no. 4, pp. 821-833.

Pearson, C.J., Regenerative, semiclosed systems: a priority for twenty-first-century agriculture, Bioscience, 2007, vol. 57, pp. 409-418.

https://doi.org/10.1641/B570506

Peterson, H.H., Barkley, A., Chacón-Cascante, A., and Kastens, T.L., The motivation for organic grain farming in the United States: profits, lifestyle, or the environment? J. Agric. Appl. Econ., 2012, vol. 44, no. 2, pp. 137-155.

Pretty, J., Farmers' extension practice and technology adaptation: agricultural revolution in 17-19th century Britain, Agric. Human Values, 1991, vol. 8, pp. 132-148.

Pretty, J., Agricultural sustainability: concepts, principles and evidence, Philos. Trans. R. Soc., B, 2008, vol. 363, pp. 447-466.
Privitera, D., The importance of organic agriculture in tourism rural, App. Stud. Agribus. Commer., 2010, vol. 4, nos. 1-2, pp. 59-64.

Rigby, D. and Cáceres, D., Organic farming and the sustainability of agricultural systems, Agric. Syst., 2001, vol. 68 , pp. $21-40$.

Rogers, E.M., Diffusion of Innovations, New York: Free Press, 1983, 3rd ed.

Rotz, C.A., Corson, M.S., Chianese, D.S., Montes, F., Hafner, S.D., Bonifacio, H.F., and Coiner, C.U., The Integrated Farm System Model: Reference Manual, Version 4.4, Washington, DC: US Dep. Agric., 2018. https://www.ars.usda.gov/northeast-area/up$\mathrm{pa} / \mathrm{pswmru} /$ docs/integrated-farm-system-model/. Accessed July 11, 2021.

Schmidtner, E., Lippert, C., Engler, B., Häring, A.M., Aurbacher, J., and Dabbert, S., Spatial distribution of organic farming in Germany: does neighbourhood matter? Eur. Rev. Agric. Econ., 2012, vol. 39, no. 4, pp. $661-683$.

Schreefel, L., Schulte, R.P.O., de Boer, I.J.M., Pas Schrijver, A., and van Zanten, H.H.E., Regenerative agriculture-the soil is the base, Global Food Secur., 2020, vol. 26, art. ID 100404 , https://doi.org/10.1016/j.gfs.2020.100404

Sheludkov, A.V., Territorial structure and organization of agriculture in Tyumen oblast in 1973 and 2014: comparative analysis, Reg. Res. Russ., 2019, vol. 9, pp. 278287

https://doi.org/10.1134/S2079970519030080

Smith, G.A.E., The industrial problems of Soviet agriculture, Critique, 1984, vol. 14, no. 1, pp. 41-65. https://doi.org/10.1080/03017608408413288

Sustainable Agriculture-Beyond Organic Farming, Clark, S., Ed., Basel: Multidiscip. Dig. Publ. Inst., 2016.

Taus, A., Ogneva-Himmelberger, Y., and Rogan, J., Conversion to organic farming in the continental United States: a geographically weighted regression analysis, Prof. Geogr., 2013, vol. 65, no. 1, pp. 87-102.

The State of Food and Agriculture 1980, Rome: UN Food Agric. Org., 1981. http://www.fao.org/3/ap660e/ap660e.pdf. Accessed July 11, 2021.

The World of Organic Agriculture. Statistics and Emerging Trends 2021, Willer, H., Trávníček, J., Meier, C., and Schlatter, B., Eds., Bonn: Res. Inst. Org. Agric., 2021. https://www.fibl.org/fileadmin/documents/shop/1150-organic-world-2021.pdf. Accessed July 11, 2021.

Toward Sustainable Agricultural Systems in the 21st Century. Washington, DC: National Academies Press, 2010. https://doi.org/10.17226/12832

van Mansvelt, Ya.D. and Temirbekova, S.K., Organic agriculture: principles, experience, and perspectives, $S-k h$. Biol., 2017, vol. 52, no. 3, pp. 478-486.

Wezel, A., Bellon, B., Doré, N., Francis, C., Vallod, D., and David, C., Agroecology as a science, a movement and a practice. A review, Agron. Sustainable Dev., 2009, vol. 29 , pp. 503-515.

https://doi.org/10.1051/agro/2009004 